\title{
Challenges Facing Local Contractors Working with Chinese Contractors in Addis Ababa Building Projects
}

\author{
Solomon Esaiyas ${ }^{1}$, Girmay Kahssay ${ }^{2}$ \\ ${ }^{1}$ Civil Engineering, Addis Ababa Science and Technology University, Addis Ababa, Ethiopia \\ ${ }^{2}$ Civil Engineering, Addis Ababa University, Addis Ababa, Ethiopia
}

Email address:

ew.sol224@yahoo.com (S. Esaiyas), e.solomon448@gmail.com (S. Esaiyas)

${ }^{*}$ Corresponding author

To cite this article:

Solomon Esaiyas, Girmay Kahssay. Challenges Facing Local Contractors Working with Chinese Contractors in Addis Ababa Building Projects. American Journal of Civil Engineering and Architecture. Vol. 8, No. 4, 2020, pp. 87-96. doi: 10.11648/j.ajce.20200804.12

Received: July 15, 2020; Accepted: July 30, 2020; Published: September 14, 2020

\begin{abstract}
Building construction projects particularly represents one of the largest sectors of the construction industry. Currently, the rise in construction of high rising buildings are observed in Addis Ababa, the capital city of Ethiopia. The number and size of building construction projects that are being constructed in the city are increasing through time and most of these projects were being carried out by Chinese contractors. Local contractors are also involved in those projects via a subcontracting strategy. However, it is not easy for local contractors to succeed by working with their foreign counterparts who have massive international experience and capacity. The aim of this study was assessing and identifying the challenging factors affecting local contractors' performance in Chinese building projects in Addis Ababa. In order to achieve the objectives of this study, both quantitative and qualitative research approach were used with primary and secondary source of data. This study employed three types of data collection techniques such as a questionnaire surveys, interviews and observations. The target population for this study are local contractors and consultants involved in building projects that are carried out by Chinese contractors. In this study the researcher used Census/Parametric method of survey. That mean all target population of this study are included in this investigation, based on the consent and willingness of the participants. The Relative Importance Index (RII) was used as an instrument for analyzing data collected through questionnaire in tabular form by using Likert's scale of five ordinal measures. Based on the analysis, it was found that the most challenging factors affecting local contractors' performance in Chinese building projects were financial constraints, information exchange problems, cultural differences, unfamiliarity with Chinese work methodology and project complexity with a RII value of $0.84,0.81,0.77,0.73$ and 0.71 respectively. This study also identified and discussed the major cause and impact of those challenges and proposed measures to minimize their effect on the local performance in the upcoming projects through interviews from respondents and analyzed by using content analysis.
\end{abstract}

Keywords: Local Contractors, Chinese Contractors, Subcontracting, International Building Projects, Challenges

\section{Introduction}

The construction industry is the key indicator of economic performance in both developed and less developed nations [1]. Undeniably, even with its ups and downs, the industry keeps on playing a vital role in supporting economic growth [2]. As indicated in the recent report the sector keeps on being among the most essential and developing sector in Ethiopia's economy. According to the report the Minister of Ministry of Urban Development and Construction Eng. Aisha Mohammed indicated that the industry has important contribution to the Ethiopian economy, as demonstrated by its share in gross domestic product (i.e. $9.5 \%$ in 2016) [3].

Despite its significant role and accomplishments in the last couple of years, the sector has encountered challenges such as quality related problems, time and cost overrun which attributes to its poor performance. Furthermore, shortage of competent, registered and certified human resource together with lack of effective project management system and behavior of the industry to adopt the dynamism of the technology has given rise to low productivity [3].

The current rapid growth of Ethiopian construction 
industry brought about increased number of contractors joining the construction business [4]. Nowadays, the number of contractors in local construction industry is increasing from year to year. However, the large number of local contractors involved in infrastructures development lack experience and capacity to undertake major projects [5].

As a part of one measure to this, the Government of Ethiopian has opened the door for foreign contractors to take part in the Ethiopian construction sector [5]. Foreign contractors are pulled to Ethiopia for its political stability, predictable development and relatively good legitimate framework when compared to other African nations [6].

This fact has also resulted in development of the Construction sector, with many contractors now engaged in a variety of construction works. These works are however not considered to be large size due to the Local contractors lack the necessary capacity and international experience to engage in the management of Mega projects. Therefore, it has become a given that most mega projects are sourced out to foreign contractors.

In view of developing local capacity, the Government has now instituted a strategy of engaging local contractors as subcontractors in those construction projects. however, Local contractors are blamed for their poor performance and criticized for having limited technological and managerial knowhow due to failure to meet performance targets.

In consideration of these factors, this research intends to investigate the major challenging factors that affect the performance of local contractors in Chinese building projects. With the aim of identifying the major factors affecting local performance in those projects, the researcher identifies and analyzes the major causes of those challenges and finally suggests measures to reduce the impact of those challenges.

\section{Literature Review}

\subsection{The Development of the Ethiopian Construction Industry}

The evolution of modern construction industry in Ethiopia is considered to be a recent phenomenon [7]. The recent two decades are the period that the industry has drastically changed [8]. After the change of government in 1991 an increase in projects was observed. There was not only a steady growth in number of engineering projects financed locally, but the contribution of foreign financing agencies also increased [9].

Nowadays, the country has been busy with undertaking large and complex infrastructure developments. The construction of new roads, high rising buildings, dams, water works projects and airfields are among the major construction activities currently being undertaken [10] as cited by [11]. These mega projects are however carried out by foreign contractors as projects demand modernized specialist expertise which is mostly missing locally, resulting in mega projects being undertaken by foreign construction firms [12] as cited by [11].

The practice of international contracting in Ethiopian construction industry covers the period prior to the year 1968 [7]. During this period, the industry was dominated by foreign contractors such as Italians, Swedish, French, German and British [13], as cited by [11]. The necessary skilled manpower was also largely employed from abroad [7]. During the Italian occupation of the 1930's, there were some construction activities, particularly in the construction of roads [14] as cited by [9]. While, during the Military Government which came to power in 1974, foreign contractors' involvement decreased due to the establishment of state-owned construction firms [7]. However, after the change of government in 1991 an increase in the participation of international contractors was observed [9]. Considering the importance of their involvement, and contribution to the Ethiopian construction industry the government has encouraged foreign firms to engage [6]. This scenario has continued to date where most large-scale projects are awarded to foreign contractors.

On the other hand, the involvement of local contractors in Ethiopian construction sector is a recent phenomenon, with most notable works undertaken since 1968 when some small domestic contractors emerged. During the imperial era, the government took initiatives to build capacity and enhance the competitiveness of local contractors through awarding construction projects [7]. During the Military regime, State owned construction firms were established and awarded construction projects without competitive bidding [7]. This trend has been reversed since 1991 when the new Government introduced policy measures that led to the revival of the participation of the private sector in the construction industry. As a result, the role of private has started flourishing while that of public companies diminishing since $1991[15,7]$.

\subsection{The Concept of Subcontracting Practice}

Subcontracting is a long-standing practice, which has been turned out to be a conventional method for project delivery, especially for the specialist works [16]. Engaging subcontractors to carry out an undertaking is the basic practice in the current developing industry [17].

Dividing construction activities and subcontracting the works to a number of specialists allows each trade of work to be accomplished in the most affordable way [16].

However, most of small and medium-sized construction companies operate as subcontractor and also, sometimes as main contractor. Large companies may also work as a subcontractor in large consortia, for example for large-scale infrastructural developments. Based on the project size, the necessary qualifications of the personnel, and the equipment needed to realize the project, they may decide to operate as main contractor or to opt for a subcontractor role [18].

The main reasons for subcontracting construction 
companies in construction project involves the required quality of works, since subcontractors are seen as 'specialists' in their own fields and sharing part of the risks such as financial related risks, completion risks, and quality risks [19-21] as cited by [22].

\subsection{Factors Affecting Subcontractors Performance in Other Countries}

Construction projects have complexity in its nature because it contains large number of stakeholders such as clients, contractors, consultants, regulators bodies and others.
The basic goal of those stakeholders is to achieve the completion of project within time and stipulated budget. But due to nature of construction industry i.e. one of the most complex, fragmented, schedule and resource driven industry, it is always facing serious problems [23].

A number of research studies have been carried out to identify the various subcontractor's performance related factors in construction projects. Based on the revision of various literatures from different countries, the following are identified as the leading challenging factors that affect subcontractor's performance in construction industry.

Table 1. Factors affecting Subcontractors Performance.

\begin{tabular}{|c|c|c|c|}
\hline \multirow{2}{*}{ No. } & \multicolumn{2}{|c|}{ Study conducted } & \multirow{2}{*}{ Factors affecting Subcontractors Performance } \\
\hline & In & By & \\
\hline 1 & South Africa & [24] & $\begin{array}{l}\text { Weak management practices; } \\
\text { 1) Poor attitudes within subcontracting organizations } \\
\text { 2) Lack of working capital, } \\
\text { 3) High levels of competition } \\
\text { 4) Skills shortages }\end{array}$ \\
\hline 2 & Pakistan & [25] & $\begin{array}{l}\text { 1) Quality of service provided by subcontractors } \\
\text { 2) Lack of cooperation } \\
\text { 3) Excessive material wastage } \\
\text { 4) Difficult to coordinate activities }\end{array}$ \\
\hline 3 & Nigeria & [22] & $\begin{array}{l}\text { 1) Time to implement variation order } \\
\text { 2) Average delay in regular payment } \\
\text { 3) Time needed to rectify defects } \\
\text { 4) Time taken for material arrival } \\
\text { 5) Time consumed by accidents } \\
\text { 6) Contractor cash flow on the project } \\
\text { 7) Material and equipment cost } \\
\text { 8) Cost of variation orders } \\
\text { 9) Material wastage } \\
\text { 10) Safety cost }\end{array}$ \\
\hline 4 & Malaysia & [26] & $\begin{array}{l}\text { 1) Lack of subcontractor skills } \\
\text { 2) Payment issues, } \\
\text { 3) Safety issues, } \\
\text { 4) Partnering issues, } \\
\text { 5) Productivity issues }\end{array}$ \\
\hline 5 & Jordan & [27] & $\begin{array}{l}\text { 1) Subcontractor's knowledge } \\
\text { 2) Technical skills, experience and qualification. } \\
\text { 3) Health and safety issues } \\
\text { 4) Project complexity, } \\
\text { 5) Work schedule and subcontractor's private bidding. } \\
\text { 6) Superintendent capability, } \\
\text { 7) Project manager relationship and communication. } \\
\text { 8) Financial capabilities and Environmental factors. }\end{array}$ \\
\hline
\end{tabular}

\section{Research Methodology}

\subsection{Study Area}

This study begins by identifying the challenging factors affecting local contractors' performance who work with Chinese contractors., then assess the cause and impact of those challenges on their performance.

This study was conducted in Addis Ababa, the political capital of Africa and the capital city and the Economic, Political and Social Centre of Ethiopia. In recent years there has been a massive infrastructure development as the Government attempts to Develop the City to reflect its Local and international significance.

\subsection{Study Approach and Data Collection Tools}

Both quantitative and qualitative approaches of researches are used in this study with both source of data that were used to collect necessary data that is required to complete this study. This study employed a variety of data collection techniques such as questionnaire surveys, interviews and literature reviews highlighting their relations with observed facts.

\subsection{Target Population and Sampling}

The target population for this study are local contractors and consultants involved in large-scale building construction projects that are undertaken by Chinese contractors in which 
the local contractors are engaged as a subcontractor.

In this study the researcher used Census or Parametric method of survey. That mean all the target population of this study are included in this investigation, based on the consent and willingness of the parties.

\subsection{Pre-Study}

In order to cope up with validity concerns a pre-testing was conducted by construction experts and individuals who have good experience in the research area before conducting a final questionnaire survey.

The purpose of pre-study was to verify the adequacy and/or to determine the extent to which a measuring instrument provides adequate coverage of the topic under study and finally to improve the questionnaire in order to obtain the best possible results from the respondents [28].

However, findings of the experts ended up with some additional elements as a challenging factor for local contractors involved in Chinese building projects.

Finally, some minor modifications and additions were introduced to the questionnaire with the expert suggestions and the final Questionnaire was constructed before distributing them among the specified respondents.

\subsection{Data Analysis Method}

The Relative Importance Index (RII) method was adopted to establish the relative importance of the factors challenging local contractor working with Chinese contractor in case of Addis Ababa Building Projects, as adopted by [29]. Likert's scale of five ordinal measures of agreement towards each statement were used to calculate the RII for each factor that is used to determine the relative ranking.

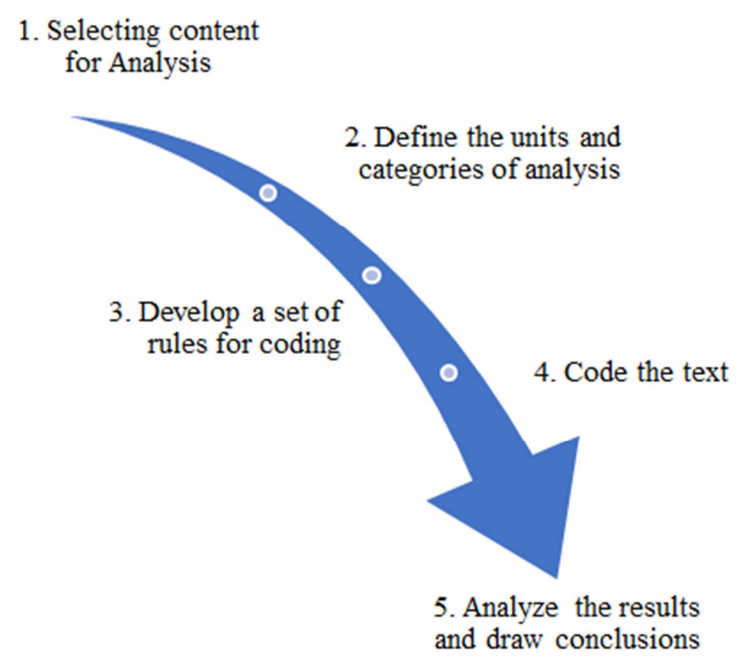

Figure 1. Steps for Content Analysis.

The RII values of each factor were attained by using the following equations.

$$
\mathrm{RII}=\left(\frac{\sum \mathrm{w}}{H x N}\right), \quad(0 \leq \mathrm{RI} \mathrm{I} \leq 1)
$$

Where, $\mathrm{W}$ is the weight given to each factor;

$\mathrm{H}$ is the largest scale available and

$\mathrm{N}$ is the number of volunteers answered the question.

The researcher analyzed the data collected through openended questions part of questionnaire survey and interviews by using Content Analysis Method.

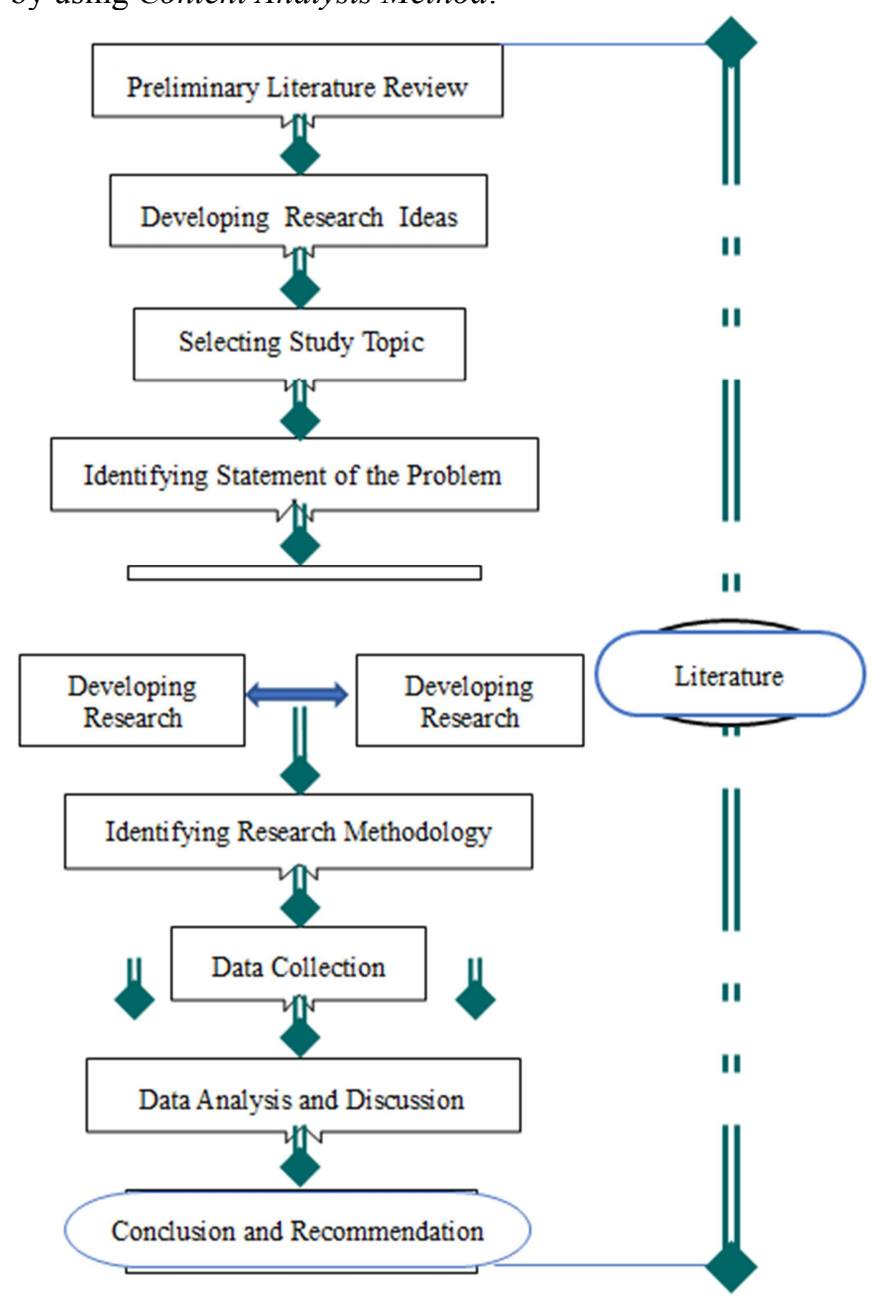

Figure 2. Flow Chart of the Research.

\section{Data Analysis and Discussion}

This section focuses on analysis of the data obtained from the participants through questionnaire survey, interviews and observations. The analysis of data obtained from the questionnaire survey as well as the interviews based on the response of questionnaire survey are presented and analyzed in this section.

A summary of the findings of the research were discussed highlighting their relations among observed facts and demonstrate their significance.

\subsection{Response Rate}

Part one of the questionnaire deals with general information about the respondents participated in this study. Accordingly, the questionnaire was distributed among the 
professional from the local contractors and the consultants.

Table 2 below shows the organizations and their distributions, including the response rate.

Table 2. Respondents Response Rate.

\begin{tabular}{lllll}
\hline \multirow{2}{*}{ No. } & \multirow{2}{*}{ Organizations } & \multirow{2}{*}{ Distributed (No.) } & \multicolumn{2}{l}{ Returned } \\
\cline { 4 - 5 } & & (No.) & $\mathbf{( \% )}$ \\
\hline 1 & Local Contractors & 19 & 17 & 89 \\
2 & Consultants & 12 & 9 & 75 \\
& Total & 31 & 26 & 84 \\
\hline
\end{tabular}

From the table 2 above, the questionnaire was distributed among a total of 31 respondents working for local contractors and consultants. From the total of 31 questionnaires distributed, 19 were distributed to professionals working for local contractors and 12 were distributed to professionals working for consultants. From the 31 questionnaires distributed among the participants, a total of 26 were responded (17 from the Local contractor side which accounts for $65 \%$ and 9 from the consultant side which is $35 \%$ of total response). From the total of the 27 questionnaires returned, 2 $(8 \%)$ were invalid and/or incomplete and the remaining 24
$(92 \%)$ valid questionnaires were analyzed according to the specified data analysis method.

\subsection{Analysis of Challenging Factors}

This section focuses on analysis of challenging factors that local contractors face while working in Chinese building projects with the response which are obtained from the professionals who are working for local contractors and consultants. This part of study provides the RII and ranking of challenging factors that face local contractors.

The reason for adopting RII and Likert's scale is to provide simplicity for the respondent to answer and make the evaluation of collecting data easier.

As shown in a table 3 below there are 10 challenging factors that are believed facing local contractor while working with their foreign counter parts. These challenging factors were obtained from different literature reviews and with some addition from the local expert through interviews during pre-study and collected, analysed and summarized according to past studies.

Table 3. Summary of Challenging Factors.

\begin{tabular}{|c|c|c|c|c|c|c|c|}
\hline \multirow{2}{*}{ No. } & \multirow{2}{*}{ Challenging Factors } & \multicolumn{2}{|c|}{ By Local Contractors } & \multicolumn{2}{|c|}{ By Consultants } & \multicolumn{2}{|c|}{ Combined Respondents } \\
\hline & & RII & Rank & RII & Rank & RII & Rank \\
\hline 1 & Lack of technical know-how & 0.55 & 9 & 0.60 & 10 & 0.57 & 9 \\
\hline 2 & Unavailability of personnel with high experience and qualification & 0.61 & 7 & 0.78 & 2 & 0.67 & 7 \\
\hline 3 & Cultural difference & 0.78 & 3 & 0.75 & 5 & 0.77 & 3 \\
\hline 4 & Unfamiliarity with Chinese Work Methodology & 0.71 & 4 & 0.75 & 5 & 0.73 & 4 \\
\hline 5 & Delay in regular payment & 0.59 & 8 & 0.78 & 2 & 0.65 & 8 \\
\hline 6 & Financial constraints & 0.81 & 2 & 0.90 & 1 & 0.84 & 1 \\
\hline 7 & Project Complexity & 0.70 & 5 & 0.73 & 7 & 0.71 & 5 \\
\hline 8 & Information exchange problems & 0.83 & 1 & 0.78 & 2 & 0.81 & 2 \\
\hline 9 & Variation and Change orders & 0.51 & 10 & 0.63 & 9 & 0.55 & 10 \\
\hline 10 & Difficulties of adopting Chinese managerial practice & 0.69 & 6 & 0.73 & 7 & 0.70 & 6 \\
\hline
\end{tabular}

As discussed in the previous sections, Relative Importance Indices (RII) Method have been carried to identify the above challenging factors. These factors were ranked in their order of importance. The ranking of those factors that affecting local contractors' performance in Chinese building projects are summarized by selecting the 5 major challenging factors among the 10 factors from combined analysis as shown in the table 4 below.

Table 4. Top 5 Challenging Factors.

\begin{tabular}{|c|c|c|c|c|c|c|c|}
\hline \multirow{2}{*}{ No. } & \multirow{2}{*}{ Challenging Factors } & \multicolumn{2}{|c|}{ By Local Contractors } & \multicolumn{2}{|c|}{ By Consultants } & \multicolumn{2}{|c|}{ Combined Respondents } \\
\hline & & RII & Rank & RII & Rank & RII & Rank \\
\hline 1 & Financial constraints & 0.81 & 2 & 0.90 & 1 & 0.84 & 1 \\
\hline 2 & Information exchange problems & 0.83 & 1 & 0.78 & 2 & 0.81 & 2 \\
\hline 3 & Cultural difference & 0.78 & 3 & 0.75 & 5 & 0.77 & 3 \\
\hline 4 & Unfamiliarity with Chinese Work Methodology & 0.71 & 4 & 0.75 & 5 & 0.73 & 4 \\
\hline 5 & Project Complexity & 0.70 & 5 & 0.73 & 7 & 0.71 & 5 \\
\hline
\end{tabular}

Therefore, based on the response and analysis the following discussion are indicated for the above major challenging factors.

1. Financial Constraints

Financial constraints have been identified by different researchers as the major factors affecting contractors project performance. This issue is not a new one, in fact it has been reported in most construction projects. For instance, in the study conducted in Jordan, financial difficulties faced by contractors were considered the primary and most frequent factor affecting contractor performance in Jordanian construction projects by the owners, the second most important according to the contractors and the third most important according to the consultants [30].

In the present study, the factor was considered the primary and most challenging factor affecting local contractor performance in Chinese building projects by the combined response with the RII value of 0.84 . Local contractors and 
consultants separately ranked the factor in the second and first position with the RII of 0.81 and 0.90 respectively.

This emphasizes that, the financial capability of a contractor has a crucial part to play as far as performance of any construction projects performance is concerned, because the financial strength of the contractors enables them to implement their works smoothly and/or unlike those with low financial capacity who wait for payments to be honored before they can carry on with the remaining work.

However, it is observed that most of the local companies involved in Chinese building projects are small sized firms and new entrants having low financial capacity as well as lack of technical and managerial experiences in the similar nature of works, who may need financial and managerial support to effectively run their business. Furthermore, it is observed that the large number of local construction firms involved in Chinese building projects are organized in a sole proprietorship which is standalone and/or independent business owned by single individual, which indicates that their financial source is only dependent on that single investor. In such types of business organizations, it could be difficult to raise capital.

During interviews sessions, interviewees indicated the existence of financial related factor they observed during their execution such as cash flow shortage for procuring raw materials and poor access to hire and/or purchase of equipment due to the fact that they do not have easy access to credit facilities. One of the respondents also indicated that their firm somehow faced difficulty of issues related to the regular / timely payment of wages and monthly staff salaries.

Due to the fact that most of the local contractors often rely on a regular payment from a project to implement their works. However, construction project has always been linked to payment delay. One of the biggest consequences of delays in the regular payment and low financial capacity is that it prevents contractors from satisfying the financial requirements to achieve project objectives. The impact of the issues were explained in a similar way by [31] and [32].

\section{Information Exchange Problem}

Any stakeholder and/or any individual familiar with construction business will agree that the proper exchange of information can be a major issue and/or a key to success, especially for construction projects involving different stakeholders with different cultural background and area of expertise. The problems associated with the exchange of information can affect the overall performance of parties involved with a variety of negative consequences on the overall construction process and/or outputs. In this research context, information exchange problem represents the problems associated with the exchange and/or transfer of project data and instructions among the Chinese contractors and local contractors.

In the present study, the factor was considered by the combined response of the respondents as the second most challenging factor with the RII value of 0.81 , while the local contractors and consultants separately ranked the factor in the first and second position with RII of 0.83 and 0.78 respectively. This shows the importance of proper exchange and/or transfer of project data and/or information among Chinese and local contractors.

During the interview session, the interviewees indicated the existence of information exchange related factors they observed during their execution such as unclear instruction from the Chinese project managers and/or supervisor and inadequate communication practice on technical matters mainly due to language difference.

However, for a smooth flow of information exchange on a construction projects, an effective communication system is required [33]. Concerning the communication issues, it is observed that most of Chinese managers and/or workforce on site prefer to communicate in their language and/or do not speak English. This issue may cause a confusion and/or misunderstanding between the professionals and could affect knowledge transfers by restricting the opportunities for the interpersonal relationships.

Some respondents indicated that this issue somehow solved by the use of interpreter. However, as indicated by some researchers and/or academics the presence of an interpreter somehow reduces the clarity and the spontaneity of information exchanges since the transfer and/or sharing of knowledge and/or information got lost in translation.

\section{Cultural Difference}

In the context of this research "cultural difference" can be described as an overall difference in an organizational management style, approach to construction, workforce competence and/or attitude, levels of capacity to do the work and differences in goals, values and strategies of the organization.

As indicated by different researchers, large-scale infrastructure developments have become increasingly multicultural, especially for countries with shortage of competent and skilled workforce together with lack of effective project management system. This multicultural issue may easily create problems.

In the present study, the factor was considered the third most challenging factor affecting local contractor performance in Chinese building construction projects by the analysis of combined response with the RII value of 0.77 . The local contractors and consultants separately ranked the factors in the third and fifth position with RII of 0.78 and 0.75 respectively.

During the interviews, some interviewees indicated that the local work force involved in Chinese building projects does not have the same work culture and/or the same commitment to work when contrasted with their foreign counterparts. For instance, one interviewee indicated that the occupational health and safety practices by local contractor and/or local employees appear to be far less than in the Chinese. According to the respondent, this different cultural perceptions of acceptable levels of safety may lead to the relationship problems between local and Chinese construction firms and prevent the emergence of trust relationships between the parties.

Some respondents indicated that most of the construction 
projects that are executed usually requires modernized specialist expertise which is mostly missing locally. These lacks of specialist expertise prevents the emergence of trust relationships between Chinese and local contractor. Due to the fact, most of the time Chinese construction companies gave working opportunity for their citizen than local firms and/or workforce.

4. Unfamiliarity with Chinese Work Methodology

In the context of this research "Work Methodology" can be described as an overall methodology any construction companies adopts to carry out the intended tasks. These methods adopted in any construction business are an organizational approach to construction activities such as methods to be employed in constructing the works; methods to be used in procuring the necessary resources; methods to be used in handling site safety, quality management and site traffic management practices and measures to be taken to minimize the negative consequence resulting from the execution of the works.

In the present study, unfamiliarity with Chinese work methodology was considered the fourth most challenging factor affecting local contractor performance in Chinese building construction projects by the combined response with the RII value of 0.73 . The local contractors and consultants separately ranked the factors in the fourth and fifth position with RII of 0.71 and 0.75 respectively.

As discussed above most of the local companies involved in those Chinese building projects lack technical and managerial experiences in the similar nature of works. On the other hand, Chinese contractors are known for having huge capital as well as long years of technical and managerial experiences in large-scale projects.

During the interview session, interviewees indicated that the unfamiliarity of local contractors to the methods adopted by the Chinese contractors have an effect on the local contractors' performance. Moreover, lack of experience in similar nature of work with Chinese, an inadequate approach and/or insufficient knowledge and experience with various tools and/or construction machineries and techniques required for the whole process and lack of familiarities with some materials used in performing their task are identified by the respondents as the major work methodology related factors which somehow lead them to poor flexibility in their work (i.e. the issues prevented the local from the usual way of conducting work) and somehow affected adaption of the new environment.

\section{Project Complexity}

As indicated by different researchers, project complexity is all about the measure of the difficulty of executing a planned construction activity due to the involvement and integration of different stakeholder with different cultural backgrounds, extensive use of sophisticated machineries and knowledge required to perform the required task.

In the present study, the factor was considered by the analysis of the combined response of respondents as the fifth most challenging factor local contractor face while working in Chinese building projects with the RII value of 0.71 . While, the local contractors and consultants separately ranked the factors in the fifth and seventh position with RII of 0.70 and 0.73 respectively.

Generally, the complexity of a project is characterized with the need for high technical skills, competent human resources and managerial capabilities. Conversely, local contractors involved in those Chinese building projects experience shortage of many of these requirements.

During the interviews, the interviewees indicated the existence of project complexity related factor they observed during their execution such as lack of experienced local workforce, company's unfamiliarity with modern technologies, poor local work attitude and/or culture and information exchange complexity (degree of obtaining exact information and poor channels of communication due to variety of language involved), mainly due to lack of past experience in similar nature of work executed.

\subsection{Causes of Challenging Factors}

This section focuses on the analysis and discussions of causes of challenging factors that the local contractors face while working in Chinese building projects. This part of study provides the RII and ranking of cause of challenging factors. As shown in a table 5 below there are 5 major cause of challenging factors that were obtained from different literature reviews and some addition from the local expert through interviews during pre-study.

Table 5. Causes of Challenging Factors.

\begin{tabular}{|c|c|c|c|c|c|c|c|}
\hline \multirow{2}{*}{ No. } & \multirow{2}{*}{ Cause of Challenging Factors } & \multicolumn{2}{|c|}{ By Local Contractors } & \multicolumn{2}{|c|}{ By Consultants } & \multicolumn{2}{|c|}{ Combined Respondents } \\
\hline & & RII & Rank & RII & Rank & RII & Rank \\
\hline 1 & Lack of experience in similar nature of works & 0.86 & 3 & 0.85 & 4 & 0.86 & 3 \\
\hline 2 & Weak use of modern technology & 0.83 & 4 & 0.88 & 3 & 0.84 & 4 \\
\hline 3 & Language Issues & 0.93 & 1 & 0.90 & 2 & 0.92 & 1 \\
\hline 4 & Insufficient financial credit facilities & 0.89 & 2 & 0.93 & 1 & 0.90 & 2 \\
\hline 5 & Poor management knowhow & 0.81 & 5 & 0.83 & 5 & 0.82 & 5 \\
\hline
\end{tabular}

Therefore, based on the response and analysis, the following discussion are indicated for the above 5 cause of challenging factors.

1. Language Issues

This issue has been reported in the most large-scale construction projects by being the major factor that lead to relationship problem between the main contractor and subcontractor and create information exchange problem between the parties. In the present study, the factor has been ranked by both respondents in the first position with RII of 
0.92. This issue may cause a confusion between the parties and affect knowledge transfers by restricting the opportunities for interpersonal relationships.

2. Insufficient financial credit facilities

This factor has been ranked by both respondents in the second position with RII value of 0.90 . The local contractors and consultants separately ranked this factor in the second and first position. One of the biggest and/or greatest outcomes of this factor is that it prevents local contractors from satisfying the financial requirements.

3. Lack of experience in similar nature of works

The factor has been ranked by combined respondents in the third position with RII value of 0.86 . Large-scale infrastructure developments have become increasingly multicultural, especially for countries with shortage of competent and skilled workforce together with lack of effective project management system. Lack of experience in similar nature of works may lead to difficulty to perform the task, create relationship problems and result in trust issues.

\section{Weak use of modern technology}

This factor has been ranked by both respondents in the fourth position with RII value of 0.84 . The local contractors and consultants separately ranked this factor in the fourth and third position with RII of 0.83 and 0.88 respectively. As indicated by different researchers, local contractors are not efficient in using the modern technology. This weak use of modern technology can mostly cause the challenges local contractors face.

5. Poor management knowhow

In the present study, the factor was considered by the combined response as the fifth major cause of challenges affecting local performance. It is observed that the local firms involved in those building projects faced difficulties to perform efficiently and effectively due to poor management knowhow. This weak management practices affect their ability to perform.

Moreover, the managerial skill of the Chinese manager and unfamiliarity of local contractors to the management practice employed by the Chinese manager have an effect on the success performance of local contractors.

Generally, the management practice implemented in any construction sector includes all the management processes, related with the planning and scheduling, decision, organizing, monitoring and coordination and evaluation of the overall activities. The problems related with the practice may be discovered through problem of the above management aspects. If these management aspects are considered properly, they may help construction firms to improve their performances. Otherwise cause a critical problem to the quality of end product.

\subsection{Interview Data Analysis}

Following the analysis of data collected through a questionnaire survey, the major challenging factors that affect local contractors' performance while working with their Chinese counterparts were identified in previous section.
This section focuses on analysis of the data obtained through the interviews based on the response of questionnaire survey. In this section, a summary of the findings of the interviews were discussed highlighting their relations among observed facts.

During the interview sessions questions were raised for respondents for their opinion on the degree of agreement of the Challenging factor and asked to identify the cause and impact of those challenges and to suggest and/or recommend the possible mitigation measures to minimize the effect of those challenging factors.

The degree of agreement on the effects of the challenging factors affecting local performance in Chinese building projects varies for the respondents participated in this study. It was recognized that to some degree all of the challenging factors had some effect on local performance. However, the five major challenging factors were identified as having a greater impact than others. The reason for what made those factors the major challenging factors was discovered through interview as indicated in the discussion part of the top five challenging factors affecting local performance from the analysis of combined responses.

As for the other challenging factors, some interviewees complained about Chinese unwillingness to cooperate in some case which need toleration and compromise. On the other hand, some respondents indicated disrespecting of local workers and/or undermining of local employees by Chinese due to the mistakes made by local employees and their work culture as one of the other main challenges local contractors faced while working with Chinese contractor. While, some indicated trust issues, lack of experience of hard working and improper communication as one of the challenges that local contractors face while working with their Chinese counterparts.

As for what causes of challenges, based on the analysis obtained from the data collected through open ended questions of questionnaire survey and interviews, most of the respondents identified lack of a clear and long-lasting vision and strategy by local contractors, lack of experience in large and complex projects, weak use of modern technology, weak management practice, insufficient financial credit facilities and poor work ethics as one the major cause of the challenges local contractors face while working with their Chinese counterpart. While, slow progress, poor work experience, cost overruns, quality related issues, dispute between local and Chinese firms and reduced involvement range of locals in those building projects were considered by the interviewees as the major impact of challenges.

As a result, participating local contractors in international collaborations, engaging local contractors in continuous training and development program, provide free on job training to local contractor to make them familiar with Chinese work methodology, provide clear information and guidance on matters un familiar to locals and providing the financial support for local firms were suggested as the most common solutions to minimize the effect of the challenging factors. 
Knowledge sharing was considered primary and the most important benefit and/or best practice local contractor gain by working with construction companies with different work cultures. During the interviews, the interviewees highlighted the importance of knowledge transfer and/or sharing. It is believed that interacting with stakeholders having different cultural backgrounds and areas of expertise can give significant advantages for local improvements and a project to be successful. Interviewees indicated good work experience, technology transfer, good management system, creativity and problem-solving skill, good work ethics and improved site safety practice as the major benefits local contractor gain through the knowledge transfer.

\section{Conclusion}

Ethiopian rapid economic growth has fueled a recent wave of construction in all over the country and the construction sector has been going through lots of changes in the last two decades. Nowadays, construction of buildings and roads (i.e. new roads, maintenance and upgrading of existing roads) have been going on almost everywhere in the country.

However, this unexpected boom in the construction industry is beyond the capacity of Ethiopian construction companies. Due to the fact different construction companies from different regions of the world are marching to Ethiopia for benefiting themselves and the state as well.

Apart from its vital role in overall development strategies, the current trend of Ethiopian Construction is worsening the indigenous key participants of the industry as it seems favoring foreign firms in most projects executed and on those still in progress. Nowadays, many high-rise buildings are being built in Addis Ababa and most of them are being under taken by Chinese contractors. Although local contractors are involved in those projects via a subcontracting strategy. However, it is not easy for local firms to succeed by working with their foreign counterpart who have massive international experience.

The aim of this research was identifying the challenges local contractors face while working with Chinese contractors, by assessing their cause and impact and finally suggesting ways to reduce those challenges. Accordingly, this study has identified, analyzed and discussed the major challenges facing local contractors who worked and working in Chinese building projects and identified their major cause and impact on their performance.

Based on the findings from the analysis, financial constraints, information exchange problem, cultural difference, unfamiliarity with Chinese work methodology and project complexity are found out to be the major challenges which are greatly affecting the performance of local contractors in Chinese building projects.

As for what causes the challenges, based on the analysis obtained from the data collected through questionnaire survey and interviews, most of the respondents identified lack of a clear and long-lasting vision and strategy by local contractors, lack of experience in similar nature of works, weak use of modern technology, weak management practices and insufficient financial credit facilities as the major cause of the challenge's local contractors face. While, slow progress, poor work experience, cost overruns, quality related issues, dispute between local and Chinese firms and reduced involvement range of locals in large and complex building projects were considered by the interviewees as the major impact of challenges facing local contractors.

The interviewees responded to the challenging factors minimization question by stating the opposite of what was stated in the factors that contribute to the challenging factors.

\section{Data Availability Statement}

The readers can access the data underlying the findings of this study by contacting the author through the author's email address: e.solomon448@gmail.com.

\section{Conflicts of Interest}

The authors declare that there are no conflicts of interest regarding the publication of this paper.

\section{Acknowledgements}

My special and heartily thanks to my advisor Dr. Girmay Kahssay who encouraged, guided, directed and give helpful comments for the successful completion of this research work. I also express my gratitude to all respondents for assisting me in providing all the necessary information.

Finally, I would like to express my appreciation for my beloved parents, who encouraged and prayed for me throughout the time of my research.

\section{Funding Statement}

This research was funded by Ministry of Science and Higher Education, Ethiopia.

\section{References}

[1] A. Ngowi, Ed."Challenges facing construction industries in developing countries," Building Research \& Information, vol. 30, no. 3, pp. 149-151, 2002.

[2] J. Fischgrund and V. Omachonu, "Quality in Construction: Identifying the Gaps," International Journal of Construction Engineering and Management, vol. 3, no. 2, pp. 65-73, 2014.

[3] ENA, "Ethiopia: Construction Industry Crucial for Successful Transformation of Economy - Construction Minister," 2018.

[4] Z. T. Zewdu, "Construction Projects Delay and Their Antidotes: The Case of Ethiopian Construction Sector", International Journal of Business and Economics Research, vol. 5, no. 5, pp. 113-122, 2016.

[5] A. T. H/Gebriel, "Model Development for improving the Performance of Projects: A Case Study on Ethiopian Roads Authority (ERA)," 2004. 
[6] A. Getahun, "Comparative analysis on the factors affecting performance of local and international contractors in road projects administered by Ethiopian roads authority," Addis Ababa, 2016.

[7] EEA, "The Current State of the Construction Industry: Report on the Ethiopian Economy," vol. VI, 2008.

[8] A. Y. Anshebo, "Performance Assessment of Public Building Construction Projects in Addis Ababa", Addis Ababa, 2017.

[9] K. Girmay, "Claims in International Projects in Ethiopia", Addis Ababa, 2003.

[10] A. Dinku, "Insurance Requirements and Practices of Ethiopia's Construction Sector," 2000.

[11] M. M. Gebre, "The Role of Financial Institutions for The Ethiopia's Construction Industry," 2006.

[12] W. Jekale, "Development of the Construction Industry in Ethiopia," EACE Bulletin, vol. 4, no. 1, pp. 9-16, 2005.

[13] W. Jekale, "Performance for public construction projects in developing countries: Federal road and Educational Building projects in Ethiopia," Norway, 2004.

[14] B. Abate, "Proposed Affirmative Action for Building the Capabilities of Domestic Contractors", 2002.

[15] B. Berhanu, "Comparative Financial Performance of Domestic and Foreign Construction Companies in Ethiopia", Addis Ababa, 2009.

[16] F. Yik, J. Lai, K. T. Chan and E. Yiu, "Best Practices in Managing Specialist Subcontracting Performance: Final Report", Construction Industry Institute, 2006.

[17] X.-H. Jin, G. Zhang, B. Xia and Y. Feng, "Relationship between Head Contractors and Subcontractors in the Construction Industry: A Critical Review," in Seventh International Conference on Construction in the 21st Century (CITC-VII) "Challenges in Innovation, Integration and Collaboration in Construction \& Engineering”, Bangkok, Thailand, 2013.

[18] EIM, "EU SMEs and subcontracting: Final report," Business \& Policy Research, 2009.

[19] J. Mbachu, "Conceptual framework for the assessment of subcontractors' eligibility and performance in the construction industry," Construction Management and Economics, vol. 26, no. 5, pp. 471-484, 2008.

[20] H. A. Hailu, "Determinants of Subcontracting Performance in Road Construction Projects: Case of Addis Ababa Road Projects," International Journal of Scientific Engineering and Research, vol. 6, no. 7, pp. 1-7, 2018.
[21] D. Gunderson and W. Rick, "General Contractors Perceptions of Subcontractors: Attributes and Competencies: A Pacific Northwest Study," in 48th ASC Annual International Conference Proceedings, 2013.

[22] S. O. Olatunji, D. O. Aghimien, A. E. Oke and T. M. Akinpelu, "Assessment of the Use of Subcontracting Options for Construction Project Delivery," Civil and Environmental Research, vol. 8, no. 5, 2016.

[23] A. H. Memon, I. A. Rahman and A. A. A. Azis, "Preliminary Study on Causative Factors Leading to Construction Cost Overrun.," International Journal of Sustainable Construction Engineering \& Technology, vol. 2, no. 1, 2011.

[24] CIDB, "Subcontracting in The South African Construction Industry; Opportunities for Development," 2013.

[25] R. M. Choudhry, J. W. Hinze, M.ASCE, M. Arshad and H. F. Gabriel, "Subcontracting Practices in the Construction Industry of Pakistan," Journal of Construction Engineering and Management, 2012.

[26] L. Yoke-Lian, S. Hassim, R. Muniandy and L. Teik-Hua, "Review of Subcontracting Practice in Construction Industry," IACSIT International Journal of Engineering and Technology, vol. 4, no. 4, pp. 442-445, 2012.

[27] J. M. Assbeihat, "Factors affecting the performance of Electromechanical Subcontractors in Construction Projects (Jordan case)," European International Journal of Science and Technology, vol. 5, no. 2, pp. 32-40, 2016.

[28] M. Usman, "Project Management Competence and Complexity in Projects: Impact Study on Performance of Mega Engineering Projects in Pakistan," 2018.

[29] W. Kifle, "Factors Affecting Time Performance of Local Road Contractors on Federal Road Construction Projects," Addis Ababa, 2013.

[30] R. Sweis, L. Bisharat, S. Bisharat and G. Sweis, "Factors Affecting Contractor Performance on Public Construction Projects," Life Science Journal, vol. 11, no. 4s, pp. 28-39, 2014.

[31] A. Rahman, "Significant Factors Causing Cost Overruns in Large Construction Projects in Malaysia," Journal of Applied Sciences, vol. 13, no. 2, pp. 286-293, 2013.

[32] O. Ameh and E. Osegbo, "Study of Relationship between Time Overrun and Productivity on Construction Sites," International Journal of Construction Supply Chain management, vol. 67, no. 1, 2011.

[33] S. B. Lagiman, "Improvement of Relationship between Main Contractor and Subcontractor for Successful Construction Project Implementation," 2017. 